\title{
The Relationship between Preservice Teachers' Attitudes towards Statistics and Their Research Anxiety
}

\author{
Adnan Taşgın (iD) 1,*, Yasemin Kaya (iD) 1 \\ ${ }^{1}$ Atatürk University, Faculty of Education, Department of Educational Sciences, 25100, Erzurum-Turkey
}

\section{ARTICLE HISTORY}

Received: 27 August 2018

Revised: 12 October 2018

Accepted: 17 October 2018

\section{KEYWORDS}

Attitudes towards statistics, Research anxiety,

Attitude,

Preservice teacher

\begin{abstract}
The aim of this study was to investigate the relationship between preservice teachers' attitudes towards statistics and their research anxiety. The population of the study consisted of the students of a public university in Turkey who were studying at the Guidance and Psychological Counseling, and the Preschool Education programs. From this population, 257 participants were sampled for this research based on scale sampling method. In order to determine the attitudes and the anxiety of the participants towards statistics and research, two separate scales were to the participants. The scale of attitudes towards statistics consisted of 33 items, which assessed five subscales. The scale of research anxiety consisted of 12 items measuring a single factor. The data were analyzed through independent samples t-test and correlation analyses. The study results suggested that the female preservice teachers had more positive attitudes towards statistics than the male preservice teachers. On the other hand, the male preservice teachers' research anxiety levels were lower than the female preservice teachers. Moreover, the attitudes and the anxiety levels showed significant differences based on the departments of the preservice teachers in favor of the Guidance and Psychological Counseling department. Finally, a positive correlation found between the research anxiety and the attitudes towards statistics levels of the participants.
\end{abstract}

\section{INTRODUCTION}

While traditional statistical teaching methodology focuses on formulas, calculations and processes, it is usually criticized because of not using statistics to solve real life problems, and because of not focusing on interpreting, criticizing and evaluating skills of students (Mvududu, 2005; Büyüköztürk, 2000; Barnet, 1999; Köklü, 1996; Köklü, 1994; Hogg, 1992; Watts, 1991; as cited in Doğan, 2009).

Statistics is stated as a central science that is used in educational and social sciences (Ridgway, Nicholson, \& McCusker, 2007). It is also emphasized that there is no scientific field without statistics (Griffith, Adams, Gu, Hart \& Nichols-Whitehead, 2012). Nowadays, statistics is an 
interdisciplinary science that is constantly evolving with new research and methodologies, and it can be applied to every scientific field. Statisticians bring healthy marketing openings to many areas of their countries such as finance, health, economy, agriculture and education with their researcher identities. They also provide notable contribution to solve existing social problems. Especially in our country, the importance of statistics and statisticians is gradually increasing within the scope of European Union studies (Salihova \& Memmedova, 2017).

An examination of the students' attitudes towards statistics is important because it might be relevant to learning process (Griffith et al., 2012). It is a fact that students' attitudes towards statistics are known to have the power to influence their success of statistics course. It is stated that statistics courses have the power to affect many university students' academic career (Parker, Pettijhon, \& Keillor, 1999; Potter, 1995). Ramirez, Schau and Emmioğlu (2012) emphasize that positive attitudes towards statistics are important for learning. Moreover, individuals with negative statistical attitudes are likely not to use statistics in the future. Dweck (2002) suggests that positive attitudes have a positive effect on students' behaviors, motivations and achievements. In order to investigate the results of technological development on statistics education, Cebeci and Bek (1999) have founded the first school, which provides online statistical education in Turkey, the Alfa Virtual Statistics School. Doğan (2009) conducted a research to determine whether computer supported statistics education effects students' achievement levels in statistical courses and their attitudes towards statistics. The study resulted that the use of computers in the statistics course (using internet, visual materials, statistical software) increased the positive attitudes towards statistics and the achievement level in the statistics course.

Anxiety is another variable of this research that is defined as a condition that can result in unpleasant emotional situations accompanied by physiological symptoms (Feist, 1990). It is also expressed as a sense of tension, which emerges with sadness, worrying thoughts, concern, and the thoughts of something bad is going to happen (TDK, 2017). Today, anxiety is a reaction of human being to various destructive and disruptive situations directed towards the individual's own being or the things he or she identifies (Canbaz, Sünter, Aker, \& Peksen, 2007). Anxiety is a complex feeling of unknown origin (Başaran, 2005).

Research anxiety arises from behaviors such as not doing research unless you have to, feeling bored when you need to do research, feeling uncomfortable with the idea of doing research, and feeling nervous and not trusting yourself when doing research (Çokluk-Bökeoglu \& Yılmaz, 2005). It is also stated that individuals' academic potential beliefs are influential on their academic achievement (Patall, Awad \& Cestone, 2014).

The previous research findings about the students' attitudes towards research and the students' research anxiety concluded that the college students had negative attitudes towards research (Büyüköztürk, 1997) and their research anxiety levels were found moderate (Çokluk-Bökeoglu \& Y1lmaz, 2005). A study showed that the graduate students' research anxiety levels differentiated across universities, faculties, their grade level, and whether the students took statistics and measurement courses or not (Saracaloğlu, Varol \& Evin, 2003). The graduate students showed high research anxiety levels, and their research competence levels decreased as their research anxiety levels increased (Tekin, 2007). Different studies agreed that students experienced high and intense levels of anxiety in statistics and research methods courses (Onwuegbuzie \& Wilson, 2003; Sanders, 2001; Trimarco, 1997), and taking a research methods course reduced their research anxiety (Unrau \& Beck, 2004). On the other hand, Saracaloğlu (2008) conducted a research over graduate students and contrarily found that their level of academic motivation was adequate, research anxiety was low and attitudes towards research was positive. 
The objective of our study is to investigate the relationship between the attitudes of preservice teachers towards statistics and their research anxiety. Within this scope, the following research questions have been developed:

Q1: Are the attitudes of preservice teachers towards statistics differentiated across gender?

Q2: Are the attitudes of preservice teachers towards statistics differentiated across their departments?

Q3: Is there a significant relationship between the attitudes of preservice teachers towards statistics and their research anxiety?

\section{METHOD}

\subsection{Research Model}

The methodology of this study was survey research. Survey research design enables researchers to depict population tendencies, attitudes or opinions qualitatively or quantitatively through the studies applied on the sampled units that were obtained from the population itself (Creswell, 2013).

\subsection{Population and Sample}

The study population existed of the undergraduate students that are studying in the Preschool Education and the Guidance and Psychological Counseling departments at a state university in Turkey. The sample consisted of 257 preservice teachers determined according to the criterion sampling method. The sample in the study was chosen according to a certain criterion which was to take a statistics course in the semester when the study was conducted. The distribution of the sample according to the variables is given in Table 1.

Table 1. Distribution of Sample According to Gender and Department

\begin{tabular}{|c|c|c|c|c|}
\hline Variables & & & $\mathbf{N}$ & $\%$ \\
\hline \multirow{3}{*}{ Gender } & Female & & 186 & 72.4 \\
\hline & Male & & 71 & 27.6 \\
\hline & & Total & 257 & 100.0 \\
\hline \multirow{3}{*}{ Department } & Preschool Education & & 107 & 41.6 \\
\hline & Guidance and Psychological Counseling & & 150 & 58.4 \\
\hline & & Total & 257 & 100.0 \\
\hline
\end{tabular}

\subsection{Instruments}

In the course of the study, the data were obtained by applying two different scales to determine preservice teacher attitudes towards statistics and their research anxiety.

\subsubsection{Attitudes towards Statistics Scale}

The scale developed by Yaşar (2014) consists of 33 items and 5 subscales. The subscales of the scale are named as the Relation of Statistics and Professional Life (7 items), Statistical AnxietyFear (9 items), Enjoying Statistics (6 items), the Importance of Statistics (6 items), and Statistical Difficulty Perception. The scale is a 9-point Likert-type scale with a level of agreement varying from "I do not agree" (1) to "I definitely agree" (9). Receiving a high score from the scale is an indicator of a positive attitude towards statistics, but it is opposite for a low score. The calculated Cronbach-Alpha internal consistency coefficient for the data obtained from this research sample is $\alpha=.92$.

\subsubsection{Research Anxiety Scale}

The "Research Anxiety Scale" developed by Büyüköztürk (1997) is a five-point Likert-type scale consisting of 12 items that are loading on a single factor. The scale has five positive (items 
$1,5,6,7,9,10$, and 12) and seven negative (items 2, 3, 4, 8, and 11) items. Negative items are encoded in reverse order. Receiving a high score on the scale indicates low research anxiety, while the low score indicates high research anxiety. The Cronbach-Alpha internal consistency coefficient calculated for the data obtained from this research sample is $\alpha=.93$.

\subsection{Data Analysis}

In the analysis process, first a missing values analysis was undertaken. Little's MCAR test indicated that the data were missing at random, $\chi^{2}=201.318, p=.860$. Therefore, the missing data were resolved replacing the missing values with the related variable mean. Then, it has been checked whether the data met the assumptions of normality (Shapiro-Wilk, $p>.05$ ) and equality of variances, which are among the assumptions of parametric tests. After testing the normality of the data, the independent samples t-test was conducted to compare the scores of the two different participant groups. The relationship between two variables was examined through Pearson's correlation coefficient.

\section{RESULTS}

Table 2 shows the results of the independent samples t-test that has been conducted to examine whether the preservice teachers' attitudes towards statistics and research anxiety differ across gender.

Table 2. $t$-test Results Comparing Males and Females on Attitudes Towards Statistics and Research Anxiety

\begin{tabular}{lllcllll}
\hline Scale & Gender & $\mathrm{N}$ & $\bar{X}$ & $\mathrm{sd}$ & $t$ & $\mathrm{df}$ & $\mathrm{p}$-value \\
\hline Attitudes Toward & Female & 186 & 188.51 & 39.04 & \multirow{2}{*}{2.461} & \multirow{2}{*}{255} & \multirow{2}{*}{015} \\
Statistics & Male & 71 & 174.35 & 46.58 & & & \\
\hline \multirow{2}{*}{ Research anxiety } & Female & 186 & 41.16 & 11.54 & \multirow{2}{*}{-2.027} & \multirow{2}{*}{255} & \multirow{2}{*}{.044} \\
& Male & 71 & 44.39 & 11.13 & & & \\
\hline
\end{tabular}

According to the results presented in Table 2, a statistically significant difference was found between the mean attitudes towards statistics scores of the female $(\bar{X}=188.51)$ and the male ( $\bar{X}=174,35)$ preservice teachers, in favor of female individuals, $\left[\mathrm{t}_{(255)}=2.461, p<.05\right]$. On the other hand, the mean research anxiety scores of the female $(\bar{X}=41.16)$ and the male $(\bar{X}=$ 44.39) preservice teachers were found significantly different in favor of male teachers, $\left[\mathrm{t}_{(255)}=\right.$ $-2.027, p<.05]$.

The results of the independent samples t-tests that are conducted to examine whether the attitudes of the preservice teachers towards statistics and their research anxiety levels differ across departments are given in Table 3.

Table 3 shows that a statistically significant difference was found between the mean attitudes towards statistics scores of the guidance and psychological counseling $(\bar{X}=173.21)$ and the preschool education ( $\bar{X}=192.72)$ students, in favor of the preschool education students, $\left[\mathrm{t}_{(255)}=\right.$ $-3.797, p<.05]$. On the other hand, the mean research anxiety scores of the guidance and psychological counseling $(\bar{X}=45.15)$ and the preschool education $(\bar{X}=37.70)$ students were found significantly different in favor of the guidance and psychological counseling students $\left[\mathrm{t}_{(255)}=-5.3999, \mathrm{p}<.05\right]$. 
Table 3. t-test Results Comparing Departments on Attitudes Towards Statistics and Research Anxiety

\begin{tabular}{llcccccc}
\hline Scale & Department & $\mathrm{N}$ & $\bar{X}$ & $\mathrm{sd}$ & $t$ & $\mathrm{df}$ & Sig. Dif. \\
\hline Attitudes Toward & $\begin{array}{l}\text { Preschool Education } \\
\text { Guidance and }\end{array}$ & 107 & 173.21 & 44.31 & & & \\
& $\begin{array}{l}\text { Gutistics } \\
\text { Psychological }\end{array}$ & 150 & 192.72 & 37.74 & -3.797 & 255 & .000 \\
& Counseling & & & & & & \\
\hline Preschool Education & 107 & 37.70 & 12.85 & & & \\
Research anxiety & $\begin{array}{l}\text { Guidance and } \\
\text { Psychological }\end{array}$ & 150 & 45.15 & 9.29 & -5.399 & 255 & .000 \\
& Counseling & & & & & & \\
\hline
\end{tabular}

Pearson correlation coefficient was estimated to determine the relationship between the attitudes of preservice teachers towards statistics and their research anxiety is calculated. The obtained result is presented in Table 4 below.

Table 4. Correlation Between Attitudes Towards Statistics and Research Anxiety

\begin{tabular}{llll}
\hline & & Attitudes Toward Statistics & Research anxiety \\
\hline Attitudes Toward & Pearson & & .328 \\
Statistics & Correlation & & \\
\cline { 2 - 4 } & $\mathrm{p}$ & & .000 \\
\hline Research anxiety & $\begin{array}{l}\text { Pearson } \\
\text { Correlation }\end{array}$ & .328 & \\
\cline { 2 - 4 } & $\mathrm{p}$ & .000 & \\
\hline
\end{tabular}

The finding of the relationship between the attitudes of preservice teachers towards statistics and their research anxiety levels are given in Table 4 . The result shows that there is a significant positive correlation between the attitudes of the preservice teachers towards statistics and the anxiety about research $[r=.328, n=257, p<.01]$.

\section{DISCUSSION}

In this study, the relationship between the attitudes of preservice teachers towards statistics and their concerns about research was investigated. The results obtained from the research are explained below.

According to the analyses results that were examining the relationship between the attitudes of preservice teachers towards statistics and their research anxiety across gender, it was concluded that the female preservice teachers had more positive attitudes towards statistics that the male preservice teachers. As the literature is examined, while some research results indicate that the attitudes of female students towards statistics are more positive (Mahmud \& Zainol, 2008), some other studies prove that male students' attitudes towards statistics are more positive (Baloğlu, 2003; Tempelaar \& Nijhuis, 2007; Zeidner, 1991). More interestingly, some researchers claim no difference across gender in terms of the students' statistical attitudes (Cherian \& Glencross, 1997; Martins, Nascimento, \& Estrada, 2011; Mji, 2009; Tomazic \& Katz, 1988). It can be argued that the variability in these research results can be caused by sample differences. In terms of research anxieties, male preservice teachers were found to have less research anxiety than female preservice teachers, yet there are earlier studies that contradict this finding (Aslan \& Karagül, 2016; Büyüköztürk, 1999; Çokluk-Bökeoğlu \&Yılmaz, 2005; Saracaloğlu, Varol \& Evin-Ercan, 2005; Saracaloğlu, 2008; Trimarco, 1997; Y1lmaz \& Çokluk, 2010). 
The analysis examining the differentiation of both the attitudes of preservice teachers towards statistics and their research anxiety levels across the department variable showed a significant difference for both variables in favor of the guidance and psychological counseling students. In other words, the preservice teachers from the guidance and psychological counseling program showed more positive attitudes towards statistics and were less anxious about doing research compare to those from the preschool education program. This difference might be due to the fact that the major of guidance and psychological counseling is more concentrated on psychology and research, and the students of this program are required to take related courses more intensely. Also, as a result of the requirements of the national university entrance exam, the students who become qualified for admission to the Guidance and Psychological Counseling programs most likely to have positive attitudes towards mathematics, which might be a cause of difference as well. This interpretation is supported by literature which provides evidence of the relationship between attitudes towards statistics, research anxiety, and mathematical background, (Chiesi \& Primi, 2010; Lalonde \& Gardner, 1993; Nasser, 2004),

It is proven that there is a significant positive relationship between the attitudes of the preservice teachers towards statistics and their research anxiety. This result can be interpreted as the degree to which the preservice teachers having a positive attitude towards statistics will lead them lower research anxiety levels. This finding is supported by literature (Baloğlu, Kocak \& Zelhart, 2007; Khavenson, Orel \& Tryakshina, 2012; Rosli, Maat, \& Rosli, 2017). Similarly, related studies are suggesting that as the positive attitude toward statistics increases, the anxiety level towards statistics reduces. The results of this study are supported by the results of the existing research, which claims to prove that statistical courses and their course exams cause a high degree of anxiety on the students and consequently students' academic performances decrease (Carmona, Martínez \& Sánchez, 2005; Chiesi \& Primi, 2010; Macher, Paechter, Papousek, \& Ruggeri, 2012; Tremblay, Gardner, \& Heipel, 2000). In addition, some research results have proven that the students' statistical attitudes and anxiety levels are also related to their mathematical background (Chiesi \& Primi, 2010; Lalonde \& Gardner, 1993; Nasser, 2004). Sesé, Jiménez, Montaño and Palmer (2015) stated that the students' statistical performances were affected by their math background and statics related anxiety. Zhang et al. (2012) also stated that the attitudes of the students towards statistics could be influenced by age, statistical knowledge, research experience, and mathematical background. The findings of Onwuegbuzie (2000) that claims that roughly $75-80 \%$ of the graduate students are concerned about statistics also reveal the importance of graduating from college with a positive attitude towards statistics.

Based on the results of this study, future comparative research is suggested on the statistical attitudes of the preservice teachers and the reasons of the research anxiety differentiations across gender and department variables. In addition, the variables that might influence the attitude towards the statistic should be identified, and the tendencies of the students regarding these variables can be examined.

\section{ORCID}

Adnan Taşgın (D) http://orcid.org/0000-0002-3704-861X
Yasemin Kaya (D) http://orcid.org/0000-0003-3503-0122

\section{REFERENCES}

Aslan, C., \& Karagül, S. (2016). Anxiety levels of graduate students in Turkish language education programme about carrying out scientific research. Journal of Mehmet Akif Ersoy University Faculty of Education, 38, 201-217. 
Baloğlu, M. (2003). Individual differences in statistics anxiety among college students. Personality and Individual Differences, 34, 855-865. doi:10.1016/S01918869(02)00076-4

Baloğlu, M., Kocak, R., \& Zelhart, P. F. (2007). The relationship between statistics anxiety and attitudes toward statistics. Ankara University Journal of Faculty of Educational Sciences, 40(2), 23-39. doi:10.1501/Egifak_0000000179

Basaran, İ. E. (2005). Educational psychology. Ankara: Nobel.

Büyüköztürk, S. (1997). Development of research anxiety scale. Educational Management in Theory and Practice, 3(12), 453-464.

Büyüköztürk Ş. (1999). The relationship between anxiety and research in terms of gender, research experience and course achievement. Education and Science, 23(112), 29-34.

Canbaz, S., Sürter, A. T., Aker, S., \& Peksen, Y. (2007). The anxiety level of the interns in a medical faculty and affecting factors. Journal of General Medicine, 17(1), 15-19.

Carmona, J., Martínez, R. J., \& Sánchez, M. (2005). Mathematical background and attitudes toward statistics in a sample of Spanish college students. Psychological Reports, 97, 5362. doi:10.2466/pr0.97.1.53-62

Cebeci, Z., \& Bek, Y. (1999, May). Online statistics education: The Alfa Virtual Statistics School. Paper presented at the meeting of the first Statistics Conference, Turkish Statistical Society and Statistics Association, Belek, Antalya.

Cherian V. I., \& Glencross, M. J. (1997) Sex, socioeconomic status, and attitude toward applied statistics among postgraduate education students. Journal of the Royal Anthropological Institute, 3, 1385-1386. doi:10.2466/pr0.1997.80.3c.1385

Chiesi, F., \& Primi, C. (2010). Cognitive and non-cognitive factors related to students's statistics achievement. Statistics Education Research Journal, 9(1), 6-26.

Creswell, J. W. (2013). Research design: Qualitative, quantitative, and mixed methods approaches. ( $4^{\text {th }}$ ed.). London: SAGE.

Çokluk-Bökeoglu, Ö. \& Yılmaz, K. (2005). The relationship between attitudes of university students towards critical thinking and research anxieties. Educational Administration: Theory and Practice, 11(41), 47-67.

Doğan, N. (2009). The effect of computer-assisted statistics instruction on achievement and attitudes toward statistics. Education and Science, 34(154), 3-16.

Dweck, C. (2002). Messages that motivate: How praise molds students' beliefs, motivation, and performance (in Surprising Ways). In J. Aronson (Eds.), Improving academic achievement: Impact of psychological factors on education (pp. 37-60). USA: Elsevier Science.

Feist, J. (1990). Theories of personality. Worth, TX: Holt, Rinehart, and Winston.

Griffith, J. D., Adams, L. T., Gu, L.L., Hart, C. L., \& Nichols-Whitehead, P. (2012). Students' attitudes toward statistics across the disciplines: A mixed-methods approach. Statistics Education Research Journal, 11(2), 45-56.

Khavenson, T., Orel, E., \& Tryakshina, M. (2012). Adaptation of survey of attitudes towards statistics (SATS 36) for Russian sample. Procedia - Social and Behavioral Sciences, 46, 2126-2129. doi: 10.1016/j.sbspro.2012.05.440

Lalonde, R. N., \& Gardner, R. C. (1993). Statistics as a second language? A model for predicting performance in psychology students. Canadian Journal of Behavioral Science, 25, 108-125. doi: 10.1037/h0078792

Macher, D., Puechter, M., Papousek,I., \& Ruggeri, K. (2012). Statistics anxiety, trait anxiety, learning behavior, and academic performance. European Journal of Psychology of Education, 27, 483-498. doi: 10.1007/s10212-011-0090-5 
Mahmud, Z., \& Zainol, M.S. (2008). Examining postgraduate students' perceived competency in statistical data analysis and their attitudes toward statistics. International Journal of Education and Information Technologies, 1, 79-86.

Martins, J., Nascimento, M., \& Estrada, A. (2011). Attitudes of teachers towards statistics: A preliminary study with Portuguese teachers. Paper presented at the meeting of Seventh Congress of the European Society for Research in Mathematics Education (CERME 7). Rzeszow, Poland: University of Rzeszow and ESRM. Retrieved from http://www.cerme7.univ.rzeszow.pl/WG/5/CERME_Martins-Nascimento-Estrada.pdf

Mji, A. (2009). Differences in university students' attitudes and anxiety about statistics. Psychological Reports, 104, 737-744. doi:10.2466/PR0.104.3.737-744

Nasser, F. (2004). Structural model of the effects of cognitive and affective factors on the achievement of Arabic-speaking pre-service teachers in introductory statistics. Journal of Statistics Education, 12. Retrieved from: http://www.amstat.org/publications/jse/v12n1/ nasser.html

Onwuegbuzie A. J. (2000). Attitudes toward statistics assessments. Assessment \& Evaluation in Higher Education, 25(4), 321-339. doi: 10.1080/713611437

Onwuegbuzie, A. J. \& Wilson, V. A. (2003). Statistics anxiety: Nature, etiology, antecedents, effects, and treatments-a comprehensive review of the literature. Teaching in Higher Education, 8(2), 195-209. doi: 10.1080/1356251032000052447

Parker, R. S., Pettijohn, C. E., \& Keillor, B. D. (1999). The nature and role of statistics in the business school curriculum. Journal of Education for Business, 751, 51-54. doi:10.1080/08832329909598990

Patall E. A., Awad, G. H., \& Cestone, C. M. (2014). Academic Potential Beliefs and Feelings: Conceptual Development and Relations with Academic Outcomes. Self and Identity, 13(1), 58-80. doi: 10.1080/15298868.2012.738705

Potter, A. M. (1995). Statistics for sociologists: Teaching techniques that work. Teaching Sociology, 23(3), 259- 63.

Ramirez, C., Schau, C., \& Emmioğlu, E. (2012). The importance of attitudes in statistics education. Statistics Education Research Journal, 11(2), 57-71.

Ridgway, J., Nicholson, J., \& McCusker, S. (2007). Teaching statistics - Despite its applications. Teaching Statistics, 29(2), 44-48. doi: 10.1111/j.1467-9639.2007.00276.x

Rosli, M. K., Maat, S. M., \& Rosli, R. (2017). Students' attitude and anxiety towards statistics: A descriptive analysis. Research on Education and Psychology (REP), 1(1), 47-56.

Salihova, S., \& Memmedova, V. (2017). Students attitudes toward statistics lesson: Validity and reliability study. Journal of Academic View, 59, 116-127.

Sanders, L. (2001). Reducing students' anxiety in research methods. Focus on Teacher Education, 1(3), 3-9.

Saracaloğlu, A.S. (2008). The relationship between post graduate students' academic motivation level, research anxiety and attitudes with their research competence. Yüzüncü Yll University, Journal of Faculty of Education, 5(2), 179-208.

Saracaloğlu, A. S., Varol, R. \& Evin, İ. (2003, October). The relationship between the scientific research anxiety, the attitudes towards research and statistics, and the research competencies of graduate students. Paper presented at the meeting of the Contribution to Science in Education: Graduate Education Symposium, Dokuz Eylul University Institute of Educational Science, Izmir.

Saracaloğlu, A. S., Varol, S. R., \& Evin-Ercan, İ. (2005). The relationship between post graduate students' research competence and scientific research anxiety and their attitudes 
towards statistics and research. Journal of Buca Faculty of Education, 17, 187-199. Retrieved from http://dergipark.gov.tr/deubefd/issue/25433/268360

Sesé, A., Jiménez, R., Montaño, J.J., \& Palmer, A. (2015). Can attitudes towards statistics and statistics anxiety explain students' performance? Revista de Psicodidáctica, 20(2), 285304.

Tekin, M. (2007, October). Examination of the level of anxiety and proficiency of graduate students across various variables. Paper presented at the meeting of the third Graduate Education Symposium, Anadolu University Institute of Educational Sciences, Eskişehir.

Tempelaar, D. T., \& Nijhuis, J. F. (2007). Commonalities in attitudes and beliefs toward different academic subjects. In M. K. McCuddy, H. van den Bosch, J. W. B. Martz, A. V. Matveev, \& K. O. Morse (Eds.), Educational innovation in economics and business X: The challenges of educating people to lead in a challenging world (pp. 225-250). Berlin: Springer.

Tomazic, T. J., \& Katz, B. M. (1988, August). Statistics anxiety in introductory applied statistics. Paper presented at the meeting of the American Statistical Association, New Orleans, LA.

Tremblay, P. F., Gardner, R. C., \& Heipel, G. (2000). A model of the relationships among measures of affect, aptitude, and performance in introductory statistics. Canadian Journal of Behavioral Science, 32, 40-48. doi: 10.1037/h0087099

Trimarco, K. A. (1997). The effects of a graduate learning experience on anxiety, achievement, and expectations in research and statistics (Report No. TM028328). Paper presented at the Annual Meeting of the Northeastern Educational Research Association. (ERIC Document Reproduction Service No. ED 419 022)

Türk Dil Kurumu (TDK). (2017). Türkçe sözlük [Turkish dictionary]. Ankara, Türkiye.

Unrau, Y.A., \& Beck, A.R. (2004). Increasing research self-efficacy among students in professional academic programs. Innovative Higher Education, 28(3), 187 - 204. doi:10. 1023/B:IHIE.0000015107.51904.95

Yaşar, M. (2014). Attitudes toward statistics scale: Validity and reliability study. Pamukkale University Journal of Education, 36(36), 59 - 75. Retrieved from http://dergipark.gov.tr/ pauefd/issue/32869/374831

Yılmaz, K., \& Çokluk, Ö. (2010). Research anxiety levels of faculty of arts and science graduates. Journal of Abant Izzet Baysal University, 10(1), 1-9.

Zhang, Y., Shang, L., Wang, R., Zhao, Q., Li, C., Xu, Y., \& Su, H. (2012). Attitudes toward statistics in medical postgraduates: Measuring, evaluating and monitoring. BMC Medical Education, 12, 117. doi:10.1186/1472-6920-12-117

Zeidner, M. (1991). Statistics and mathematics anxiety in social science students: Some interesting parallels. British Journal of Educational Psychology, 61, 319-328. 